\section{¿APOYO A LUGARES 0 APOYO A PERSONAS? DOS PROYECTOS CHILENOS DE VIVIENDA SOCIALMENTE INTEGRADA'}

Francisco Sabatini ${ }^{2}$ y Luis Vergara ${ }^{3}$

\section{Resumen}

La vivienda social no segregada o vivienda de integración social es un desafío contemporáneo de la política pública. Se la conoce internacionalmente como inclusionary housing o "vivienda inclusiva". En este artículo discutiremos sus avances y debilidades en Chile, el único país latinoamericano que ha llegado a tener una política nacional de vivienda de integración social. Analizaremos críticamente dos experiencias desarrolladas en el país con base en los dos enfoques de política hoy en disputa a nivel internacional: Ribera Norte, en Concepción, basado en el apoyo a lugares; y San Alberto de Casas Viejas, en Santiago, basado en el

\section{SUPPORT FOR PLACES OR PEOPLE? TWO CHILEAN PROJECTS FOR SOCIALLY INTEGRATED HOUSING'}

Francisco Sabatini ${ }^{2}$ and Luis Vergara ${ }^{3}$

\section{Abstract}

Non-segregated social housing, or socially integrated housing, is a contemporary public policy challenge, known internationally as "inclusionary housing". In this paper we discuss its progress and weakness in Chile, the only Latin American country that has developed a national policy for socially integrated housing. We will critically analyze two experiences developed in the country based on two internationally disputed policy approaches: Ribera Norte in Concepción, a place-based approach; and San Alberto de Casas Viejas in Santiago, a peoplebased approach. Strictly speaking both experiences mix these two types of support, but in different ways. 
apoyo a personas. Veremos que, en rigor, ambas experiencias mezclan los dos tipos de apoyos, pero lo hacen de manera diferente. Con base en el análisis comparado de sus logros y limitaciones, argumentamos sobre la necesidad de rediseñar la actual política habitacional de integración social para mejorar su capacidad de hacer frente a los procesos de segregación socioespacial, específicamente a la guetización de los conjuntos de vivienda social y a la expulsión de la nueva vivienda social fuera de las ciudades.

\section{PALABRAS CLAVE: VIVIENDA DE INTEGRACIÓN SOCIAL; VIVIENDA INCLUSIVA; APOYO A PERSONAS; APOYO A LUGARES; SEGREGACIÓN SOCIOESPACIAL.}

Recibido: 28-08-2017

Aceptado: 27-08-2018

$1 \quad$ Lincoln Institute of Land Policy, Programa Anillos de Investigación en Ciencias Sociales de CONICYT y Beca de Doctorado Nacional 21151567 de CONICYT.

2 Chile. Profesor de la Pontificia Universidad Católica de Chile y de la Universidad del Bío-Bío. ORCID: http://orcid.org/0000-00018745-0052. Correo electrónico: fsabatin@uc.cl.

3 Chile. Pontificia Universidad Católica de Chile. ORCID: http://orcid.org/0000-0001-6436-0273. Correo electrónico: Ilvergara@ uc.cl.

10 revista invi 33(94) : 9-48, noviembre 2018
Based on a comparative analysis of its achievements and limitations, we argue for the need to redesign the current social integration housing policy, in order to improve its capacity to confront processes of sociospatial segregation, specifically the ghettoization of social housing and the expulsion of the new social housing outside cities.

KEYWORDS: SOCIAL INTEGRATION HOUSING; INCLUSIONARY HOUSING; SUPPORT FOR PEOPLE; SUPPORT FOR PLACES; SOCIO-SPATIAL SEGREGATION.

Received: 28-08-2017

Accepted: 27-08-2018

1 Lincoln Institute of Land Policy, CONICYT Social Science Research Program. CONICYT Doctoral Fellowship No 21151567.

2 Chile. Professor, Pontifical Catholic University of Chile and University of Bio-Bio. ORCID: http://orcid.org/0000-0001-87450052. Email: fsabatin@uc.cl.

3 Chile. Pontifical Catholic University of Chile. ORCID: http:// orcid.org/0000-0001-6436-0273. Email: Ilvergara@uc.cl. 


\section{Introducción: el problema de la segregación de la vivienda social}

Un capitalismo inmobiliario rampante, con capacidad de inducir y capitalizar "brechas de renta" (Smith, 1979) por doquier, incluso en la tradicional periferia urbana popular, está expulsando la vivienda para los hogares de bajos ingresos de nuestras ciudades como un todo. Esta voracidad rentista ha traído la ruptura del patrón tradicional de segregación de la ciudad latinoamericana (Sabatini, 2015), modelo espacial que les reservaba a las clases populares amplias secciones de la periferia urbana. Ahora, los precios del suelo suben especulativamente, especialmente en la antigua periferia popular, porque se van ajustando a la capacidad de pago de los nuevos, mejores pagadores, los hogares de clase media o alta -hogares que, de la mano de los promotores, están invadiendo más y más barrios y áreas de la ciudad. El fenómeno no solo afecta a las grandes ciudades chilenas y del continente. También se ha vuelto relevante en ciudades intermedias (Marchant, Frick y Vergara, 2016).

En tal contexto, la pregunta acerca de cómo construir viviendas para familias pobres en localizaciones no-segregadas, viviendas que ofrezcan oportunidades de integración social y funcional a la vida urbana, adquiere premura urbanística y ya no solo relevancia social en la agenda urbana.

\section{Introduction: The Social Housing Segregation Issue}

Unscrupulous real estate capitalism, which may induce and capitalize on "rent gaps" (Smith, 1979), even in traditional peri-urban areas, is currently pushing lower-income housing out of cities. This excess of rent income has disrupted traditional segregation patterns in Latin American cities (Sabatini, 2015), a spatial model that usually reserved large spaces within peri-urban areas for the working class. Today, however, there has been a constant increase in the price of land as the result of speculation, especially in the old periurban area, which has been invaded by middle and higher-income families. Such a phenomenon is not only affecting large cities in Chile and the rest of the region, but also intermediate cities (Marchant, Frick and Vergara, 2016).

In this context, the question how to build dwellings for deprived families in non-segregated areas arises. How housing can offer social and functional inclusion in urban life acquires urgency in planning and not only social relevance in the urban agenda.

The housing solutions implemented by Chilean governments to help the working classes since the end of the 1970s have been mostly focused on 
La solución que desde finales de los años setenta han entregado los gobiernos chilenos a la necesidad de vivienda de las clases populares se ha sustentado mayoritariamente en un enfoque neoliberal de apoyo a personas. Con el doble supuesto de que el bienestar de las personas está determinado mayoritariamente por su esfuerzo personal y de que los mercados son los mejores asignadores de recursos, la política "de subsidio habitacional" ha entregado cientos de miles de vouchers o subsidios estatales a familias sin ingresos suficientes para acceder a los mercados habitacionales, buscando la mutación de estos beneficiarios desde necesitados a demandantes. Mercados robustos y liberalizados de las distorsiones que la intromisión del Estado causaría en ellos, ofrecerían, dentro de un marco de competencia entre las firmas, adecuadas soluciones de vivienda a estos nuevos demandantes. Las empresas competirían por captar los vouchers y, así, la vivienda mejoraría en tamaño y calidad, todo ello en el marco del trade off entre tamaño y accesibilidad que, según Alonso (1964), sería propio de la economía urbana: a mayor tamaño de la vivienda (y terreno) menor accesibilidad al centro, y viceversa.

Un análisis de largo plazo de la política de vivienda social chilena cuestiona, sin embargo, estos supuestos, tanto los del neoliberalismo chileno como los teóricos de Alonso. Especialmente en los decenios de neoliberalismo, la vivienda social tendió a perder accesibilidad, tamaño y calidad constructiva, neoliberal people-based aid approaches. Based on the dual thought that people's wellbeing is determined by personal effort and that markets act as the main providers of resources, "housing subsidy" policies have granted thousands of vouchers or state subsidies to economically deprived families to access the housing market, thus turning need into demand. Free from state intervention, and marked by competition, this robust market would offer proper housing solutions to these new consumers. Real estate companies would compete for these vouchers and housing would improve in terms of volume and quality within a trade-off between size and accessibility which, according to Alonso (1964), would reflect the characteristics of urban economy: the size of dwellings (and land) is inversely proportional to the access to central areas.

However, the long standing analysis of Chilean social housing policies challenges the above mentioned notions, both those referring to the Chilean neoliberalism and the theories put forward by Alonso. Especially during the neoliberal period, social housing lost accessibility, size and quality at the same time (Mora, Sabatini, Fulgueiras and Innocenti, 2014). There is no significative competition between real estate companies. In fact, each city does not have a single land market, as suggested by Alonso. There is a fragmentation of complex and imperfect markets that are far removed from the ideals of free competition and transparency. 
todo al mismo tiempo (Mora, Sabatini, Fulgueiras e Innocenti, 2014). La competencia reparadora entre las empresas no existe. De hecho, no existe un único mercado de suelos en cada ciudad, como lo da por descontado el modelo de Alonso. Predomina una segmentación de mercados, de por sí complejos e imperfectos, mercados que están alejados de los ideales de libre concurrencia y transparencia.

Solo la intervención del Estado a través de normas de tamaño y calidad de la vivienda social ha logrado mejoras de la vivienda social chilena (Mora et al., 2014, p. 45). Otras intervenciones, sin embargo, no han podido torcerle la nariz a las tendencias segregadoras de los mercados de suelo. La acción de sucesivos gobiernos chilenos destinada a evitar la formación de grandes aglomeraciones de vivienda social, amontonamiento que contribuye a la guetización de los barrios, no ha tenido éxito. La prohibición de construir conjuntos de más de 300 viviendas sociales, luego rebajada a 150 unidades, no evitó que las empresas inmobiliarias operaran por etapas e hicieran crecer la segregación de gran escala (Mora et al., 2014, p. 27-28).

En vez del trade off entre tamaño y accesibilidad de Alonso (1964), lo que se ha vuelto predominante hoy bajo el capitalismo inmobiliario expansivo que vivimos es un trade off entre acceso a la ciudad y acceso a la vivienda. En efecto, los hogares de clase media y baja que no logran comprar una vivienda con sus propios medios se ven enfrentados a la disyuntiva de acceder a la ciudad o de acceder
Only the intervention of the State, through the implementation of size and quality standards, enabled the improvement of Chilean social housing (Mora et al., 2014, p. 45). However, other interventions aimed to tackle the segregating tendency of land markets have met with failure. The measures implemented by Chilean governments to prevent the spatial agglomeration of social housing - and the consequent phenomenon of ghettoizationhave proved unsuccessful. The prohibition to build developments of more than 300 units, which was then reduced to 150 units, was not effective as real estate companies built multiple, reduced but adjacent developments, thus promoting the emergence of large scale segregation (Mora et al., 2014, p. 27-28).

Rather than the size-accessibility trade-off suggested by Alonso (1964), the current expansive real estate capitalism is characterized by the predominance of a trade-off between access to the city and access to housing. In fact, middle and lower-income families who cannot purchase housing face the question as to access the city or access formal housing. If their priority -or need in many cases- is to live in the city, they are forced to live in the houses of relatives, rent rooms in poor neighborhoods or occupy land in shanty towns. On the other hand, if they decide to access formal housing -as propietors, as in the case of Chilean social housing-, they see themselves forced to sacrifice access to the city and move to segregated areas outside cities. 
a una vivienda formal. Si su prioridad -necesidad, para muchos- es vivir en la ciudad, lo deben hacer allegándose en casas de parientes, arrendando cuartos en tugurios o invadiendo suelos y asentándose en "campamentos". Si, en cambio, deciden acceder a una vivienda formal-además, en propiedad, en el caso de la vivienda social chilena- deben sacrificar el acceso a la ciudad y aceptar localizaciones segregadas, hoy a escala regional, fuera de las ciudades.

Aunque la política de apoyo a personas ha sido cuantitativamente exitosa en nuestro país, ha producido viviendas que no podrían ser catalogadas como integradas. Se localizan en conjuntos de vivienda segregada en lo social y lo funcional. Hay disponible un importante número de estudios que documentan tanto la segregación espacial de la vivienda social resultante del enfoque de apoyo a personas, como sus nocivos efectos sociales (véanse Ducci, 1997; Sabatini, Cáceres y Cerda, 2001; Rodríguez y Sugranyes, 2004; Hidalgo, 2007; Sabatini, Wormald y Rasse, 2013).

Entonces, ¿cómo construir "vivienda de integración social" bajo la economía urbana de la hora presente; esto es, vivienda en localizaciones no segregadas, que evite la expulsión de la población hacia los extramuros de la ciudad y que fomente la integración funcional y social de las familias?

Este artículo tiene como propósito revisar críticamente dos experiencias de vivienda de integración social que se han desarrollado en Chile durante las
Though people-based aid policies have succeeded in quantitative terms, they have produced dwellings that cannot be regarded as inclusive in nature. These units are located in socially and formally segregated developments. There is a wealth of research on the spatial segregation of social housing as the result of the implementation of people-based aid programs and associated negative social effects (Ducci, 1997; Sabatini, Cáceres and Cerda, 2001; Rodríguez and Sugranyes, 2004; Hidalgo, 2007; Sabatini, Wormald and Rasse, 2013).

Therefore, how can we build inclusionary housing within the current urban economy context -that is, housing located in non-segregated areas, housing that do not result in the displacement of families out of the limits of the city, and housing that fosters social and functional inclusion

The objective of this paper is to critically analyze two cases of inclusionary housing carried out in Chile over the last two decades: the Ribera Norte program, implemented in Concepcion, and; the San Alberto de Casas Viejas project, carried out in the urban expansion area of Puente Alto, Santiago.

This paper is divided into three sections. The first discusses the option between support for places and support for people based on specialized literature. This concludes with a research question that best summarizes the current challenge faced by housing policies in our cities. The following section analyzes 
últimas décadas: el programa Ribera Norte, en la ciudad de Concepción, y el proyecto San Alberto de Casas Viejas, en Puente Alto, Santiago.

El artículo se estructura en tres secciones. En la primera discutimos la opción entre apoyo a lugares y apoyo a personas con base en la literatura especializada, cerrando con la pregunta de investigación que, a nuestro juicio, mejor resume el desafío que enfrenta hoy la política de vivienda en nuestras ciudades. Luego, en la siguiente sección, analizamos los dos casos chilenos de vivienda de integración social, comparándolos según sus logros y deficiencias en cada una de las tres dimensiones principales que definen a la vivienda de integración social -a la "vivienda inclusiva" en el plano internacional: acceso al suelo no segregado, permanencia de los beneficiados y oportunidades de integración social y funcional. En la sección final, argumentaremos que una política adecuada de vivienda de integración social debe inspirarse en un enfoque de apoyo a lugares $\mathrm{y}$, al mismo tiempo, complementarse con el apoyo a personas para que éstas no sean desplazadas de los lugares mejorados -o para que no se conculque la posibilidad de que en el futuro pueden mudarse hacia dichos lugares hogares de bajos ingresos. two cases of inclusionary housing and compares them in terms of achievements and weaknesses according to the three main dimensions that define inclusionary housing: access to non-segregated land, permanence of beneficiaries in these developments and opportunities of social and functional integration. In the final section we argue that an appropriate policy for inclusionary housing should be inspired by a focus on place-based strategies and, at the same time, be complemented by peoplebased aid approaches thus avoiding displacement from improved places, nor that in the future the possibility that low-income households can move to these places is not violated. 


\section{El dilema conceptual de la política de vivienda: ¿apoyo a personas 0 apoyo a lugares?}

La estrategia de apoyo a personas se basa en la entrega de un voucher para que los sujetos, individualmente, puedan seleccionar de la oferta disponible en el mercado, una vivienda adecuada a sus necesidades. La idea que subyace bajo este enfoque neoliberal es que el funcionamiento libre de los mercados ofrece viviendas ajustadas a los requerimientos de cada tipo de hogar. El Estado entrega un aporte en dinero a la familia (voucher), que se suma al ahorro individual y, si corresponde, a un crédito obtenido en la banca.

Si las familias pudieran elegir entre lo que ofrece el mercado, el subsidio les serviría para mudarse desde barrios desfavorecidos a lugares con mejores oportunidades económicas y calidad de vida (Galster, 2017). Sin embargo, el acceso a la vivienda suele no materializarse en barrios menos segregados, y los resultados no son tan buenos (Massey, 2015; Owen, 2017). El problema del apoyo a personas, tanto en los Estados Unidos como en Latinoamérica, radica, precisamente, en la escasa capacidad de elección que las personas tienen del barrio en el que van a vivir (Boggs, 2017), dados el monto del subsidio, la capacidad de ahorro de los sujetos y el valor de la vivienda ofrecida por el mercado inmobiliario.

\section{The conceptual dilemma of Social Housing: Should help go to People or Places?}

People-based aid strategies are based on the provision of a personal 'voucher' to choose the dwelling that best suits the needs of beneficiaries within the real estate market. The idea underlying this neoliberal approach is that free markets offer tailored housing options to each type of family. The State provides financial support (voucher) to families, which complements previous savings and, if applicable, mortgage credits.

If families were able to choose what the market has to offer, the state subsidy would help them to move from deprived areas to places offering better economic opportunities and quality of life (Galster, 2017). However, access to housing is rarely obtained in less segregated spaces, delivering poor results (Massey, 2015; Owen, 2017). Both in the United States and Latin America this issue lies in the little options families have to choose the area they want to live in (Boggs, 2017) as the result of the amount of state subsidies, savings capacity and the value of dwellings.

Strictly speaking, the possibility of building social housing in neighborhoods with higher socioeconomic status would be an exception. Therefore the provision 
En rigor, la posibilidad de insertar vivienda social en barrios de mayor estatus socioeconómico sería una excepción y, por tanto, la entrega de subsidios a la demanda está lejos de garantizar buenos resultados e, incluso, como argumenta Tapia (2011) para el caso de Chile, es determinante en la segregación espacial de los más pobres.

El apoyo a lugares se posiciona como una estrategia alternativa frente al modelo del voucher habitacional. Los programas con foco en el lugar típicamente buscan revitalizar barrios intraurbanos deprimidos y así mejorar las oportunidades de sus residentes (Owen, 2017). En términos operativos, las estrategias focalizadas en el lugar suelen involucrar la construcción de vivienda de alto estándar en barrios desfavorecidos, la aplicación de políticas de desarrollo comunitario, la creación de puestos de trabajos y, al mismo tiempo, la aplicación de estrategias para preservar la vivienda asequible en zonas acosadas por el negocio inmobiliario (Galster, 2017). La estrategia supone la existencia de lo que en la literatura especializada se denomina "efecto barrio" (Sampson, 2012), asumiendo que las características sociales, funcionales y físicas del lugar de residencia tendrían relevancia en las posibilidades de desarrollo personal.

Los críticos del apoyo a lugares -resumen Crane y Manville (2008) - apuntan básicamente a tres problemas: (I) de focalización: no hay garantía que los recursos invertidos favorezcan a los más pobres dado que en los lugares deteriorados o carenciados of subsidies is far from ensuring good results and, as Tapia (2011) suggests, a key factor that explains the social segregation of those economically deprived.

Place-based aid strategies emerge as an alternative to the 'voucher' model. Place-based aid programs are aimed at the revitalization of deprived intraurban areas in order to improve the opportunities of residents (Owen, 2017). In operational terms, these strategies involve the construction of high standard housing in deprived neighborhoods, the implementation of community development policies, generate employment and preserve affordable housing in areas targeted by the real estate market (Galster, 2017). These strategies take for granted the so-called "neighborhood effect" (Sampson, 2012), assuming that the social, functional and physical characteristics of the place of residence play an important role in the emergence of personal development opportunities.

Those against place-based aid programs -Crane and Manville (2008) - refer to three issues: (I) targeting: there is no guarantee that resources were actually given to those in need as deteriorated or deprived places are also inhabited by non-poor people; (II) transparency: there are no clear criteria about the reasons to invest in one space to the detriment of another, which may serve political-electoral purposes; and (III) distorted operation of markets, as they may influence decisions about where to purchase housing. 
no solo viven pobres; (II) de transparencia: no se dispone de criterios claros sobre las razones para invertir en un lugar y no en otro, lo que, de paso, podría favorecer objetivos políticos-electorales; y (III) de distorsión de la libre operación de los mercados en tanto se ejerce influencia sobre las decisiones acerca de dónde vivir.

Los resultados sociales de las políticas basadas en apoyo a lugares son positivos. Para el caso de barrios deprimidos en ciudades de los Estados Unidos, Dillman, Horn y Verrilli (2017) señalan que ellas promueven mayor seguridad y una mejora en el valor de las propiedades (p. 286-291); y argumenta que el desafío de largo plazo de dichas políticas radica en garantizar la permanencia de las familias, por cuanto el incremento en los valores de la propiedad y mejora en la seguridad incentivan el interés de empresas y familias de mayores ingresos por estos lugares. Así, en ausencia de estrategias de resistencia, la gentrificación podría provocar el desplazamiento de residentes antiguos en esos lugares.

Aun cuando las investigaciones muestran que el apoyo a lugares tiene mejores resultados sociales que el apoyo a personas, paradójicamente este último sigue predominando, tanto en Estados Unidos como en Latinoamérica. Parece innegable que la razón principal es ideológica: la influencia que aún tienen las orientaciones neoliberales en las políticas sociales.
Place-based aid programs have rendered positive social results. In the case of deprived American neighborhoods, these strategies have promoted greater security and increased the value of properties (Dillman, Horn and Verrilli, 2017, p. 286-291). As argued by these authors, place-based aid programs face the long-term challenge of ensuring families remain in housing since the increase in the value of properties and greater security attract real estate agents and more affluent families. In this sense, the gentrification phenomenon may lead to the displacement of old residents within these areas as the result of the lack of resistance strategies.

Despite research showing that place-based aid initiatives have rendered better social results when compared with people-based aid programs, the latter approach continues to predominate in the United States and Latin America. It seems an undeniable fact that such a phenomenon is governed by ideological reasons as social policies are still influenced by neoliberal approaches.

As for the Latin American case and how to best promote inclusionary housing, some specific elements of local urban realities should be taken into consideration. The first is referred to as "segregation asymmetry" (Sabatini, Rasse, Mora and Brain, 2012; Sabatini, 2016, p. 440-441). 
En cuanto al aterrizaje latinoamericano sobre cómo promover mejor la vivienda de integración social, debemos tener en consideración algunos elementos específicos de la realidad urbana local. El primero lo podemos llamar "asimetría de la segregación" (Sabatini, Rasse, Mora y Brain, 2012; Sabatini, 2016, p. 440-441). Aunque los grupos altos y medios tienden a concentrarse en algunas áreas mejor dotadas y equipadas de cada ciudad (alta segregación), no tienen mayor inconveniente en compartir, en una escala agregada, esas áreas residenciales con otros grupos sociales. En una escala menor, sin embargo, la mayoría de las personas buscan vivir con sus iguales, como hemos encontrado en Chile (Sabatini et al., 2012) y como también es posible constatar en los Estados Unidos, con la excepción de los negros que quieren abandonar barrios guetizados (Zhang y Zheng, 2015, p. 18).

Un segundo elemento específico de la segregación en América Latina es nuestra cultura mestiza, que incluye grados apreciables de tolerancia hacia la diversidad y, a la vez, de indiferencia con la situación del "otro". La mezcla social en el espacio es más fácil cuando la tolerancia y la indiferencia predominan.

La masiva gentrificación de la periferia popular es un tercer elemento característico de "nuestra" segregación; una gentrificación que no genera, directamente y en el corto plazo, desplazamiento de los
Despite medium and higher-income groups being mainly concentrated in the most favorable areas of each city (high segregation), they have no problem sharing these spaces with other social groups on an aggregate scale. However, on a smaller scale, most of people want to share with their peers, as in the case of Chile (Sabatini et al., 2012) and the United States, with the exception of the Afro-American individuals who want to leave ghettoized areas (Zhang and Zheng, 2015, p. 18).

The second element characteristic of Latin American segregation is mestizo culture, which involves considerable tolerance towards diversity and, at the same time, indifference to the situation of the "other." Social mixing is more likely to happen when tolerance and indifference operate as prevailing elements.

The massive gentrification of working class periurban areas is the third element common to "our" type of segregation. This is a process that does not involve the displacement of poor groups, both directly and in a short-term basis. The result is the emergence of a socioeconomically heterogeneous peri-urban space.

These sociocultural possibilities contrast with the presence of obstacles generated by the liberalization of land markets in most of the countries of the region. As discussed above, a dynamic and aggressive real 
TABLA 1. EVOLUCIÓN DEL SUBSIDIO DE INTEGRACIÓN EN CHILE.

\begin{tabular}{|c|c|c|c|c|c|c|c|}
\hline $\begin{array}{l}\text { Nombre del } \\
\text { programa } \\
\text { habitacional }\end{array}$ & Subsidios base & $\begin{array}{l}\text { Monto } \\
\text { entregado por } \\
\text { el subsidio }\end{array}$ & $\begin{array}{l}\text { Valor máximo de la } \\
\text { vivienda a adquirir }\end{array}$ & $\begin{array}{l}\text { Bono de } \\
\text { integración }\end{array}$ & $\begin{array}{l}\text { Bono de } \\
\text { captación de } \\
\text { subsidios }\end{array}$ & $\begin{array}{l}\text { Mix mínimo de } \\
\text { viviendas }\end{array}$ & $\begin{array}{l}\text { Cantidad } \\
\text { máxima de } \\
\text { viviendas }\end{array}$ \\
\hline $\begin{array}{l}\text { Subsidio de } \\
\text { integración } \\
\text { social }\end{array}$ & $\begin{array}{l}\text { FSV + DS.40 } \\
(2007)\end{array}$ & Hasta $205^{4}$ UF & Hasta 1000 UF & $\begin{array}{l}100 \text { UF solo } \\
\text { para bene- } \\
\text { ficiarios DS. } \\
40 \text { (Clase } \\
\text { media) }\end{array}$ & Sin bono & $\begin{array}{l}30 \% \text { para FSV + } \\
30 \% \text { para DS. } 40\end{array}$ & 150 viviendas \\
\hline $\begin{array}{l}\text { Sistema } \\
\text { integrado } \\
\text { de subsidio } \\
\text { habitacional }\end{array}$ & $\begin{array}{l}\text { FSV + DS. } 01 \\
(2011)\end{array}$ & $\begin{array}{l}500 \text { UF (Para } \\
\text { grupos emer- } \\
\text { gentes) y } 350 \\
\text { UF para gru- } \\
\text { pos medios }\end{array}$ & $\begin{array}{l}\text { Hasta } 1000 \text { UF para } \\
\text { grupos emergentes } \\
\text { y hasta } 220 \text { UF para } \\
\text { grupos medios }\end{array}$ & $\begin{array}{l}\text { Hasta } 200 \\
\text { UF para } \\
\text { grupos } \\
\text { medios y } \\
\text { emergentes }\end{array}$ & Sin bono & $\begin{array}{l}20 \% \text { para } 50 \% \\
\text { más pobre del } \\
\text { país y } 20 \% \text { para } \\
\text { grupos emer- } \\
\text { gentes o clase } \\
\text { media }\end{array}$ & $\begin{array}{l}600 \text { (dos } \\
\text { etapas de } \\
300 \text { ) }\end{array}$ \\
\hline $\begin{array}{l}\text { Reactivación } \\
\text { económica e } \\
\text { integración } \\
\text { social }\end{array}$ & DS. 116 (2014) & $\begin{array}{l}\text { Hasta } 700 \text { UF } \\
\text { máximo para } \\
\text { vulnerables y } \\
\text { hasta } 350 \text { para } \\
\text { grupos medios }\end{array}$ & $\begin{array}{l}\text { Hasta } 900 \text { UF para } \\
\text { grupos vulnerables } \\
\text { y hasta } 2000 \text { UF para } \\
\text { grupos medios }\end{array}$ & $\begin{array}{l}190 \text { UF } \\
\text { máximo } \\
\text { para vul- } \\
\text { nerables y } \\
100 \text { UF para } \\
\text { sectores } \\
\text { medios. }\end{array}$ & $\begin{array}{l}\text { Para grupos } \\
\text { medios se } \\
\text { agrega bono } \\
\text { captación de } \\
\text { subsidios que } \\
\text { puede ser entre } \\
50 \text { y } 200 \text { UF, } \\
\text { dependiendo } \\
\text { del porcentaje } \\
\text { de viviendas } \\
\text { sociales del } \\
\text { proyecto }\end{array}$ & $\begin{array}{l}\text { Entre } 20 \text { y } 40 \% \\
\text { de vulnerables } \\
\text { en ciudades de } \\
\text { más de } 40 \text { mil } \\
\text { habitantes y } \\
\text { hasta } 60 \% \text { en } \\
\text { ciudades de } \\
\text { menos de } 40 \text { mil }\end{array}$ & 300 viviendas \\
\hline $\begin{array}{l}\text { Programa de } \\
\text { integración so- } \\
\text { cial y territorial }\end{array}$ & DS. 19 (2016) & $\begin{array}{l}800 \text { UF para } \\
\text { el } 50 \% \text { más } \\
\text { vulnerable y } \\
\text { hasta } 275 \text { UF } \\
\text { para clase } \\
\text { media }\end{array}$ & $\begin{array}{l}\text { Máximo de } 1100 \text { UF } \\
\text { para grupos bajos y } \\
2200 \text { UF para grupos } \\
\text { medios }\end{array}$ & $\begin{array}{l}\text { Hasta } 240 \\
\text { UF para gru- } \\
\text { pos bajos y } \\
\text { entre } 100 \text { y } \\
300 \text { UF para } \\
\text { clase media } \\
\text { (Depende } \\
\text { captación) }\end{array}$ & $\begin{array}{l}\text { Hasta } 50 \text { UF } \\
\text { para familias } \\
\text { vulnerables y } \\
\text { entre } 50 \text { y } 200 \\
\text { UF para clase } \\
\text { media }\end{array}$ & $\begin{array}{l}20 \% \text { viviendas } \\
\text { hasta } 1100 \text { UF, } \\
10 \% \text { viviendas } \\
\text { entre } 1200 \text { UF y } \\
1400 \text { UF y } 20 \% \\
\text { viviendas de } \\
\text { más de } 1.500 \text { UF }\end{array}$ & 300 viviendas \\
\hline
\end{tabular}

Fuente: elaboración propia.

4 UF (Unidad de Fomento) es una unidad monetaria chilena que se reajusta en función de la inflación. En octubre de 2018, el tipo de cambio oficial es de aproximadamente 40 USD por UF. 
TABLE 1. EVOLUTION OF INCLUSION SUBSIDIES IN CHILE.

\begin{tabular}{|c|c|c|c|c|c|c|c|}
\hline $\begin{array}{l}\text { Housing } \\
\text { program }\end{array}$ & $\begin{array}{l}\text { Type of } \\
\text { subsidy }\end{array}$ & $\begin{array}{l}\text { Subsidy } \\
\text { amount }\end{array}$ & $\begin{array}{l}\text { Maximum } \\
\text { value of } \\
\text { dwellings }\end{array}$ & $\begin{array}{l}\text { Inclusion } \\
\text { allowance }\end{array}$ & $\begin{array}{l}\text { Allowance granted } \\
\text { according to the } \\
\text { percentage of social } \\
\text { housing included in } \\
\text { the project }\end{array}$ & $\begin{array}{l}\text { Minimum number of } \\
\text { dwellings required } \\
\text { for the provision of } \\
\text { subsidies }\end{array}$ & $\begin{array}{l}\text { Maximum } \\
\text { number of } \\
\text { dwellings }\end{array}$ \\
\hline $\begin{array}{l}\text { Social Inclu- } \\
\text { sion subsidy }\end{array}$ & $\begin{array}{l}\text { FSV + DS.40 } \\
(2007)\end{array}$ & Up to UF205 & $\begin{array}{l}\text { Up to } \\
\text { UF1,000 }\end{array}$ & $\begin{array}{l}\text { UF100 for } \\
\text { DS. } 40 \text { sub- } \\
\text { sidy holders } \\
\text { (middle } \\
\text { class) }\end{array}$ & None & $\begin{array}{l}30 \text { percent of FSV } \\
\text { dwellings and } 30 \\
\text { percent of DS. } 40 \\
\text { dwellings }\end{array}$ & 150 dwellings \\
\hline $\begin{array}{l}\text { Integrated } \\
\text { system for } \\
\text { housing } \\
\text { subsidies }\end{array}$ & $\begin{array}{l}\text { FSV + DS. } 01 \\
(2011)\end{array}$ & $\begin{array}{l}\text { UF500 for } \\
\text { emerging } \\
\text { groups and } \\
\text { UF350 for } \\
\text { middle-in- } \\
\text { come groups }\end{array}$ & $\begin{array}{l}\text { Up to } \\
\text { UF1,000 for } \\
\text { emerging } \\
\text { groups and } \\
\text { up to UF220 } \\
\text { for middle- } \\
\text { income } \\
\text { groups }\end{array}$ & $\begin{array}{l}\text { Up to UF200 } \\
\text { for emerging } \\
\text { middle- } \\
\text { income } \\
\text { families }\end{array}$ & None & $\begin{array}{l}20 \text { percent for the } \\
50 \text { percent of the } \\
\text { poorest population } \\
\text { and } 20 \text { percent for } \\
\text { middle-income } \\
\text { groups }\end{array}$ & $\begin{array}{l}600 \text { (divided into } \\
\text { two develop- } \\
\text { ments com- } \\
\text { posed of } 300 \\
\text { dwellings) }\end{array}$ \\
\hline $\begin{array}{l}\text { Economic } \\
\text { revitalization } \\
\text { and social } \\
\text { inclusion }\end{array}$ & $\begin{array}{l}\text { DS. } 116 \\
(2014)\end{array}$ & $\begin{array}{l}\text { Up to UF700 } \\
\text { for vulnerable } \\
\text { groups and up } \\
\text { to UF350 for } \\
\text { middle-inco- } \\
\text { me groups }\end{array}$ & $\begin{array}{l}\text { Up to UF900 } \\
\text { for vulnera- } \\
\text { ble groups } \\
\text { and up to } \\
\text { UF2,000 for } \\
\text { middle-inco- } \\
\text { me groups }\end{array}$ & $\begin{array}{l}\text { Up to UF190 } \\
\text { for vulnera- } \\
\text { ble families } \\
\text { and UF100 } \\
\text { for middle- } \\
\text { income } \\
\text { families }\end{array}$ & $\begin{array}{l}\text { UF50-UF200 for } \\
\text { middle-income groups } \\
\text { depending on the } \\
\text { percentage of social } \\
\text { housing included in } \\
\text { projects }\end{array}$ & $\begin{array}{l}20 \text { to } 40 \text { percent of } \\
\text { vulnerable people } \\
\text { living in cities over } \\
40,000 \text { inhabitants } \\
\text { and up to } 60 \text { percent } \\
\text { in cities below } \\
40,000 \text { inhabitants }\end{array}$ & 300 dwellings \\
\hline $\begin{array}{l}\text { Social and } \\
\text { territo- } \\
\text { rial inclusion } \\
\text { program }\end{array}$ & DS. 19 (2016) & $\begin{array}{l}\text { Up to UF800 } \\
\text { for } 50 \text { percent } \\
\text { of vulnerable } \\
\text { groups and } \\
\text { up to UF275 } \\
\text { for middle-in- } \\
\text { come groups }\end{array}$ & $\begin{array}{l}\text { Up to UF1100 } \\
\text { for lower-in- } \\
\text { come groups } \\
\text { and up to } \\
\text { UF2,200 } \\
\text { for middle- } \\
\text { income } \\
\text { groups }\end{array}$ & $\begin{array}{l}\text { Up to UF240 } \\
\text { for lower-in- } \\
\text { come groups } \\
\text { and UF100- } \\
\text { UF300 for } \\
\text { middle- } \\
\text { income } \\
\text { groups }\end{array}$ & $\begin{array}{l}\text { Up to UF50 for vulner- } \\
\text { able groups and UF50- } \\
\text { UF200 for middle- } \\
\text { income groups }\end{array}$ & $\begin{array}{l}20 \text { percent of dwell- } \\
\text { ings up to UF1,100, } \\
10 \text { percent of } \\
\text { dwellings ranging } \\
\text { UF1,200 to UF1,400 } \\
\text { and } 20 \text { percent of } \\
\text { dwellings valued in } \\
\text { excess of UF1,500 }\end{array}$ & 300 dwellings \\
\hline
\end{tabular}

Source: Elaborated by the author.

4 UF stands for Unidad de Fomento, a Chilean currency unit indexed according to inflation. As of October, 2018, the official exchange rate is at about USD 40 per UF. 
grupos pobres. Se va formando así una periferia que avanza en heterogeneidad socioeconómica.

Tales posibilidades socioculturales contrastan con la existencia de obstáculos derivados de la liberalización de los mercados de suelo en la mayor parte de los países de la región. Como hemos destacado párrafos atrás, un sector de promoción inmobiliaria dinámico y agresivo instala procesos de homogeneización o segregación progresiva de barrios y áreas de las ciudades.

En este contexto, la pregunta que organizará nuestro análisis de los dos casos chilenos de vivienda de integración social es la siguiente: iqué ha sido mejor para la producción de vivienda de integración social, el apoyo a lugares de Ribera Norte o el apoyo a personas de San Alberto? Luego de ofrecer una respuesta, estaremos en mejor condición de abordar la cuestión más general acerca de qué estrategia es mejor para promover la producción de esta "vivienda inclusiva" en Latinoamérica: ¿el apoyo a personas o el apoyo a lugares? estate sector is currently giving rise to increased social homogeneity, or progressive segregation of given neighborhoods or urban districts.

In this context, the question regarding the two Chilean cases of inclusionary housing arises: What is the best approach for the production of inclusionary housing, the place-based aid program implemented in Ribera Norte or the people-based aid program conducted in San Alberto? The answer to this question enables us to address the issue about the best strategy to promote inclusionary housing in Latin America: Should support go to people or places? 


\section{Dos experiencias de construcción de vivienda de integración social}

Después de presentarlas, compararemos ambas experiencias de producción de vivienda de integración social en tres dimensiones de análisis: acceso a suelo no-segregado, permanencia (no-desplazamiento) e integración social y funcional.

Las reflexiones aquí presentadas se nutren de datos empíricos recogidos por los autores y otros investigadores, en tres proyectos de investigación de largo aliento aplicados en San Alberto y Ribera Norte. Todos estos proyectos fueron trabajados a partir de metodologías mixtas, basadas en la aplicación de encuestas y entrevistas semiestructuradas a residentes y encargados de ejecución de los proyectos, así como también etnografías. En total, se aplicaron 174 encuestas y 32 entrevistas en San Alberto y 311 encuestas y 27 entrevistas en profundidad en Ribera Norte. Se incluyó también una etnografía de dos meses en este último barrio.

\section{Two Experiences of the Construction of Inclusionary Housing}

After the introduction, we will compare both inclusionary housing production experiences according to three analytical dimensions: access to non-segregated land; remaining in housing (no displacement), and; social and functional inclusion.

This paper is based on empirical data collected by the authors and other researchers from three research projects conducted in San Alberto and Ribera Norte. These projects are based on the implementation of mixed methodologies, surveys, semi-structured interviews with residents and project leaders and ethnographic approaches. A total of 174 surveys and 32 interviews were conducted in San Alberto and 311 surveys and 27 interviews were conducted in Ribera Norte. This research also includes a twomonth long ethnography conducted in Ribera Norte. 


\section{RIBERA NORTE: RENOVACIÓN URBANA SIN DESPLAZAMIENTO}

El Programa de Recuperación Urbana Ribera Norte de Concepción, creado en 1995 y aún en ejecución, es, en palabras de Alfredo Garay (2004) -uno de los arquitectos que lo diseñó- parte de "la nueva forma de hacer urbanismo" (p. 69). Son proyectos que buscan producir transformaciones más allá de sus fronteras de actuación, esto es, sobre el desarrollo de la ciudad, y por eso él prefiere llamarles "intervenciones sobre piezas urbanas" antes que "grandes proyectos urbanos" (p. 76). La innovación que aportan, dice Garay, radica en sus mecanismos de gestión, donde destacan la articulación públicoprivada y la participación ciudadana (p. 71).

Borja y Castells (1997) centran esta nueva forma de urbanismo en el "plan urbano estratégico" y destacan su aporte en mejorar la "competitividad de las ciudades", de la cual depende -argumentan-el bienestar de sus ciudadanos (p. 32). Lo ven como alternativo a la visión simplista de hacer más competitivas las ciudades a través de "la atracción de inversores a cualquier precio" (p. 31-32). La competitividad de los países, asevera Borja (1997), ya no depende de los recursos naturales, de factores relativos a la geografía o de la acumulación de capital, sino que, entre otros factores, de "un funcionamiento eficiente del sistema urbano", de la "definición de un proyecto de ciudad (o de región)

\section{RIBERA NORTE: URBAN RENEWAL WITHOUT DISPLACEMENT}

Created in 1995, the Urban Renewal Project for Ribera Norte is, in the words of Alfredo Garay (2004) -one of the architects who designed this initiative- part of a "new way of urban development" (p. 69). These projects are intended to introduce transformations that transcend the development of cities, hence being referred to as "interventions on urban sites" rather than on "large urban projects" (p. 76). According to Garay, the innovation of these initiatives lies in their management mechanisms, chief among them the presence of public-private articulation and citizen participation ( $p .71)$.

According to Borja and Castells (1997) this new way of urban development is part of a "strategic urban plan", highlighting its contribution to the improvement of "city competitiveness" and public welfare (p. 32). As these authors suggest, this new approach is an alternative to the simplistic thought that the "sheer attraction of investors" is enough to make cities more competitive (p. 31-32). In the words of Borja (1997), competitiveness among countries is no longer based on the availability of natural resources, geography-related factors or capital accumulation, but on factors such as "proper operation of urban systems", "design and marketing of city (or regional) projects" and "territorial 
y marketing del mismo", y de "una gobernabilidad del territorio basada en la cohesión social y la participación cívica” (p. 85).

De esta forma, en el marco de la recuperación de la democracia y del auge internacional de la nueva planificación urbana "estratégica", Ribera Norte descolla en el panorama chileno. Se propuso la renovación y recuperación para la ciudad de un extenso paño de suelo sobre el borde del río y a corta distancia del Centro de la ciudad. El Programa Ribera Norte vino a hacer realidad un antiguo sueño local: el de recuperar el sector deteriorado, marginal y estigmatizado de "la Costanera" -denominación que el Programa sustituye con la de "Ribera Norte".

Siendo su objetivo la "recuperación e integración del borde del río para la ciudad de Concepción en sus funciones culturales, económica y sociales", el Programa contempló el otorgamiento de viviendas formales en propiedad a los habitantes de los "campamentos" del área (asentamientos informales), buscando apartarse de la tradicional relocalización residencial de los residentes de asentamientos informales en conjuntos de vivienda en la periferia urbana (Salinas y Baeriswyl, 2017, p. 7). Aunque el Programa ha perdido fuerza en la producción de vivienda de integración social desde el terremoto de 2010, lo realizado le otorga prestancia como alternativa promisoria de desarrollo urbano para hacer frente y neutralizar la segregación socioespacial de los hogares de bajos ingresos. governance based on social cohesion and civic engagement", amongst others (p. 85).

In this way, within a context marked by the return to democracy and the international rise of the new "strategic" urban planning, Ribera Norte emerges as an outstanding example in Chile. This project aimed to renovate and revitalize large extensions of riverside areas near the downtown area of the city, thus fulfilling a long-cherished local dream: revitalize the deteriorated, marginalized and stigmatized "Costanera" -referred to by the Program as "Ribera Norte."

Designed to "revitalize and integrate the riverside area into the city of Concepción in cultural, economic and social terms", the Program involved the provision of formal housing to those living in informal settlements, thus departing from traditional initiatives based on the relocation of informal dwellers in peri-urban areas (Salinas and Baeriswyl, 2017, p. 7). Despite the reduced the ability of this Program to produce inclusionary housing after the 2010 earthquake, its contribution emerges as a promising alternative to addressing and neutralizing the sociospatial segregation of lower-income families. 
Ribera Norte representa una forma de planificación urbana alternativa, tanto a los planes urbanos formales como a los programas tradicionales de renovación urbana, ambos expulsores de los residentes más pobres de la ciudad, ya sea directamente o a través de la valorización del suelo que deriva de ellos -el primero, a través del zoning; y el segundo, a través de las inversiones estatales. El delgado y esquivo camino para hacer compatibles el mejoramiento de un área y la permanencia de sus residentes más pobres, Ribera Norte lo construyó y explotó, al menos por un tiempo.

\section{SAN ALBERTO: MEZCLA SOCIAL DEL ESPACIO SIN CONFLICTOS}

San Alberto de Casas Viejas es un conjunto residencial de 828 unidades construido entre 2006 y 2009 por una empresa inmobiliaria en la zona de expansión de la comuna de Puente Alto, al sur del área metropolitana de Santiago. Ideado por José Astaburuaga, ingeniero, y Mario Grandón, arquitecto, ambos con una larga experiencia de trabajo en vivienda social, este conjunto marcó un cambio respecto de las "plantaciones de vivienda social" -la expresión es de Martim Smolka- que la política chilena de "subsidio habitacional" venía produciendo y que albergaban, a esa altura, notorias deficiencias sociales. San Alberto puede ser considerado una reacción, paradójicamente orquestada desde fuera del Estado, a los problemas de la vivienda segregada que resultaban de aquella política.
Ribera Norte emerges as an alternative to formal urban plans and traditional urban renewal programs, which involve the displacement of poor residents, either directly through zoning or the increase in the price of land via state investments. Ribera Norte was successful in negotiating, at least for a time, the elusive way to make compatible the improvement of an area and the permanence of its poorest residents.

\section{SAN ALBERTO: SPATIAL SOCIAL MIXING WITHOUT CONFLICTS}

Built from 2006 to 2009, San Alberto de Casas Viejas is a residential development composed of 828 units located in Puente Alto, south of the metropolitan area of Santiago. Conceived by engineer José Astaburuaga and architect Mario Grandon, both with extensive experience in social housing, this space was a turning point for the "social housing farm" approach - a term coined by Martim Smolka- implemented by socially flawed "housing subsidy-based" policies. San Alberto can be considered a reaction to the problems of segregated housing that resulted from those policies, paradoxically orchestrated from outside the State.

The spatial homogeneity and isolation of these housing estates enabled the emergence of a process of ghettoization thus severely affecting the quality of life and access to opportunities for local residents. 
La homogeneidad espacial y aislamiento de muchos de estos complejos habitacionales crearon las condiciones para que comenzaran a entronizarse procesos de guetización, afectando severamente la calidad de vida y el acceso a oportunidades de quienes allí vivían. Los esfuerzos estatales por resolver dicha deuda social incluyeron diferentes programas: "Quiero Mi Barrio" (2006); "Subsidio diferenciado a la localización" (2006); "Programa de recuperación de barrios", que demuele parcial o totalmente la vivienda social guetizada con un enfoque de reducción de la densidad (desde 2006); y "Subsidio de integración social" (2007) -el que aplicó San Alberto de Casas Viejas-. Aunque con objetivos y modalidades diferentes, estos programas estuvieron basados en la entrega de subsidios a la demanda, por lo que, en estricto rigor, no modificaron el enfoque de "apoyo a personas" de la política de vivienda.

Y en eso radica una segunda sorpresa del conjunto San Alberto: operando en el marco de la política de "subsidio habitacional", logró ser rentable y socialmente mezclado a la vez, desmintiendo las voces que se alzaron en su contra. Entre esas voces destacaban, por una parte, las más soterradas que alimentaban el sobreentendido de que ese tipo de proyectos estaban condenados a los conflictos que se derivarían necesariamente de las desigualdades sociales; y, por otra parte, las de los promotores que afirmaban que no serían rentables. Resulta sorprendente que hoy estos promotores continúen desarrollando proyectos de vivienda de integración
State efforts to address this social issue involved the implementation of different initiatives: "I Love my Neighborhood" (2006), "Location Subsidy" (2006), "Neighborhood Renewal Program" - which is intended to partially or totally demolish ghettoized social housing for density reduction purposes(since 2006) and "Social Inclusion Subsidy" (2007) -implemented in San Alberto de Casas Viejas. Despite having different objectives and approaches, these programs were based in the provision of housing subsidies, which means they did not modify the "people-based aid" approach used by housing policies.

This is the second surprising element of San Alberto: despite operating within a "housing subsidy" context, it was both profitable and successful when it came to achieving social mixing, thus deflecting criticism. On the one hand, there were critical voices which said these projects would generate conflicts derived from social inequality; on the other hand, developers argued they would not be profitable at all. Surprisingly enough, these very developers are still carrying out inclusionary housing projects. In fact, Astaburuaga and Grandón (2013), in association with real estate investors, are currently promoting new projects in different areas of Santiago.

Up until 2007, it was common to observe that neighborhoods intended to house "housing subsidy" were exclusively composed of either lower or middleincome families. Based on the then-new social 
social. De hecho, Astaburuaga y Grandón (2013) están promoviendo nuevos proyectos mezclados con distintos inversionistas inmobiliarios en diferentes sectores de Santiago.

Hasta 2007, lo usual era que los barrios receptores de "subsidios habitacionales" se conformaran exclusivamente con un tipo de familia, sea de extracción popular o de clase media. Recurriendo al nuevo combinado de subsidios para la integración social, creado algo dubitativamente por las autoridades, San Alberto se atrevió a combinar subsidios de grupos populares y medios, además de habilitar viviendas para venta sin subsidio alguno, las que, en principio, estarían destinadas a familias de clase media alta o alta. La osadía de Astaburuaga y Grandón consistió en gestionar la demanda con un enfoque de redes sociales familiares y laborales preexistentes. Presentaron el proyecto a personas que trabajaban en lugares claves de la comuna (escuela, hospital, municipalidad y una gran empresa) a la vez que esperaban que estas, por el "boca a boca", dieran a conocer el proyecto a sus familiares. Las premisas de esta estrategia fueron: I) que, si las personas se conocen previamente, aumenta la disposición a vivir en diversidad social y II) que la necesidad de contar con una red de apoyo y familiar cercana se complementaría con las disparidades en la situación económica intrafamiliar (Sabatini, Mora, Polanco y Brain, 2013).

Así, San Alberto inauguró una nueva forma de construir barrios de vivienda social en Chile: la que inclusion subsidies, which were hesitantly developed by authorities, the aim of San Alberto was to house lower and middle-income groups. This project even conceived the construction of non-subsidized dwellings initially aimed at upper-middle and higher families. The bold idea of Astaburuaga and Grandón consisted in managing demand with a focus on pre-existent social family and labor networks. The project was introduced to local actors working in key entities (schools, hospitals, the municipality and large companies), who were expected to spread the word about this initiative. Such a strategy was based on two premises: I) if people already know each other there is an increased willingness to coexist with individuals from different social backgrounds, and II) the need for support and family networks would be complemented with intra-family unequal economic situations (Sabatini, Mora, Polanco and Brain, 2013).

In this way, San Alberto introduced a new way of how to build social housing in Chile: the promotion of social mixing. The instrument that regulates these projects (the combination of "social inclusion subsidies") has undergone permanent changes since 2007, including the increase in the amount of subsidies (see Table 1). These modifications attracted the interest of the real estate sector, especially from 2014 onwards. In fact, there were 105,000 units under construction by the end of 2017; in the words of the then head of the Ministry of Housing and 
promueve la mixtura social. El instrumento que regula estos proyectos (la combinación de subsidios que se conoció como "subsidio de integración social") ha experimentado cambios permanentes desde el 2007 a la fecha, todos ellos acompañados de un aumento en el monto de los subsidios entregados (Tabla 1). Dichas modificaciones han conseguido atraer el interés inmobiliario, especialmente desde el 2014 a la fecha. En efecto, hacia fines de 2017 había 105.000 viviendas construyéndose en todo el país bajo esta modalidad, y la ministra de Vivienda y Urbanismo de entonces declaraba que "nuestro mayor desafío hoy es que los conjuntos habitacionales garanticen mixtura social" ("Ministra Saball en conferencia", 2016).

\section{ANÁLISIS COMPARADO 1: ACCESO AL SUELO NO SEGREGADO}

La localización no segregada es la esencia de la vivienda de integración social y, al mismo tiempo, su componente más difícil de lograr. Los mercados de suelo, por su propia naturaleza imperfecta, son expulsores de los "malos pagadores" - de la vivienda social, en este caso-. En el fragor de la competencia, las áreas intraurbanas van quedando para los mejores pagadores y, con ello, perdiendo heterogeneidad social y funcional, proceso que Jacobs llama "autodestrucción de la diversidad" (Jacobs, 1961). Es un desarrollo que afecta también a las áreas de la periferia bajo gentrificación y a las áreas
Urban Planning: "our main challenge is to secure social mixing" "Ministra Saball en conferencia", 2016).

\section{COMPARATIVE ANALYSIS 1: ACCESS TO NON- SEGREGATED LAND}

Finding non-segregated areas is the essence of inclusionary housing and the most difficult goal to achieve. Land markets, due to their imperfect nature, tend to displace those referred to as "bad payers." Within a context marked by competition, intraurban areas become available for those with ability to pay, thus leading to a loss of social and functional heterogeneity $-a$ process referred to by Jacobs as "self-destruction of diversity" (Jacobs, 1961). This also affects gentrifying areas and deteriorated spaces with potential urban use undergoing renewal processes, such as San Alberto and Ribera Norte, respectively.

Against this backdrop, there are only two financing options to access housing in non-segregated land: State intervention in the increase in the price of land (value capture) or channeling subsidies to relevant programs or inclusionary housing policies from extra-urban resources. In this case, while Ribera Norte fits the first option -state-owned lands transferred to the Program (over 100ha) with the "opportunity cost" of using these areas for 
degradadas con potencial de uso urbano y en recuperación, como han sido los casos de San Alberto y Ribera Norte, respectivamente.

Con el trasfondo de esta operatoria de los mercados de suelo, las alternativas de financiamiento del suelo no segregado para la vivienda social se reducen a dos: manejo estatal de la valorización del suelo (captura de plusvalías), o canalización de subsidios hacia el respectivo programa o política de vivienda de integración social desde fondos extra urbanos. Mientras que Ribera Norte se ajusta a la primera alternativa -suelo de propiedad estatal aportado al Programa (sobre 100 ha), con el "costo de oportunidad" de no haberlo destinado a usos posibles más rentables-, San Alberto consigue suelo para vivienda de integración en base a subsidios a la demanda financiados con fondos generales de la Nación.

Una política de vivienda de integración social sustentable en el tiempo es la que se autofinancia con la movilización de las plusvalías, con la riqueza que va creando la ciudad misma en su desarrollo. Smolka ejemplifica esta cualidad de productora de riqueza que tiene la ciudad, comparando el costo de 10 a 35 dólares por metro cuadrado de las obras de urbanización de un sector de la periferia occidental de Rio de Janeiro con el incremento de entre 34 a 145 dólares por metro del precio de esos mismos terrenos (Smolka, 2013, p. 7).

Jacobus (2015) destaca que las políticas de "vivienda inclusiva" aprovechan las ganancias económicas more profitable purposes-San Alberto obtains land through state-funded subsidies.

Sustainable inclusionary housing policies are selffinanced through the land value capture and the resources generated by the development of cities. Smolka provides an example of this resource generating ability of cities by comparing the initial cost of USD10 to USD35 per square meter of developable land in the western peri-urban area of Rio de Janeiro with the further increase in USD34 to USD145 per square meter in this very area (Smolka, 2013, p. 37).

As Jacobus (2015) points out, "inclusionary housing" policies use the economic gains derived from increasing real estate values to incorporate affordable housing into the construction of marketbased housing and commercial developments. Likewise, Calavita and Mallach (2010) suggest that "inclusionary housing" initiatives use urban planning systems to create affordable housing and promote social mixing through the capture of resources generated by the market. The channeling of benefits derived from the increase in the price of land from private agents -either proprietors or urban promoters - to the funding of inclusionary housing may take many forms, such as Ribera Norte.

On the other hand there is the case of San Alberto which, instead of funding access to non-segregated land through the channeling of resources from 
que derivan de valores inmobiliarios en alza para amarrar la creación de vivienda económica a la construcción de desarrollo habitacional y comercial de mercado. Por su parte, Calavita y Mallach (2010) señalan que la "vivienda inclusiva" hace uso del sistema de planificación urbana con el fin de crear vivienda económica y promover la mezcla social por la vía de capturar recursos creados a través del mercado. El desvío de la valorización del suelo desde los agentes privados que usualmente la captan, propietarios o promotores, hacia el financiamiento de los terrenos para vivienda de integración, puede tomar muchas formas, siendo la de Ribera Norte una de ellas.

San Alberto está en las antípodas: en vez de financiar el acceso a suelo no segregado desviando plusvalías desde sus destinatarios privados "naturales", lo hace traspasando subsidios hacia esos agentes. El subsidio a la demanda habitacional se trasfiere en parte a precios del suelo, cuyo incremento equivale a la capitalización de rentas de la tierra por parte de propietarios y promotores. Por lo mismo, cada programa o política de vivienda de integración social así diseñada resulta insustentable en el tiempo. Desde su creación hacia 2007, el subsidio habitacional "de integración social" ha consistido en una serie sucesiva de subsidios de valor incremental. Esta peculiar política de vivienda de integración social se financia con una transferencia creciente de subsidios desde el Estado a los compradores de vivienda en conjuntos mezclados, "natural" private recipients, it transfers subsidies to these agents. Housing subsidies are partly transferred to land, whose increase in price is capitalized on by proprietors and urban promoters. As a result, each program or inclusionary housing policy designed according to this approach is unsustainable through time. Since its creation in 2007, the "social inclusion" subsidy has been gradually increased. This particular inclusionary housing policy is funded through the increased transfer of state subsidies to those purchasing housing in mixed developments. In this case, the price of land is the item that benefits most from state resources.

This transfer of subsidies is a general feature of Chilean "housing subsidy" policies: subsidies should be increased to offset rises in land prices. According to a study, the proportion represented by the price of land in the unit cost of social housing went from 7.3 percent in 1994 to 19.8 percent over the 20022004 period (Brain and Sabatini, 2006). Since the land markets of the traditional popular periphery were activated with the arrival of condominiums for the middle-class and, consequently, prices rose more than in the rest of the city, the transfer must have been greater in order to access land with higher opportunity costs.

San Alberto, despite succeeding when it came to social mixing, was difficult to replicate due to the high opportunity cost of available land in other 
donde la partida que más sube y absorbe estos recursos estatales es el precio o renta del suelo.

Dicha transferencia es una característica general de la política de "subsidio habitacional" chilena: el subsidio debe irse incrementando para absorber el alza de los precios del suelo que ayuda a producir. Un estudio estimó que la proporción que representa el valor del suelo en el costo unitario de la vivienda social subió de 7,3 por ciento en 1994 a 19,8 por ciento en 2002-4 (Brain y Sabatini, 2006). Desde que los mercados de suelo de la periferia popular tradicional se activaran con la llegada de los condominios para clase media, y que, consecuentemente, los precios crecieran más allí que en el resto de la ciudad, la transferencia ha debido ser mayor con el fin de acceder a terrenos con costos de oportunidad mayores.

El proyecto San Alberto, a pesar de su buen resultado en materia de mezcla social, como detallaremos más adelante, era difícil de replicar precisamente porque los terrenos equivalentes disponibles en la ciudad tienen un alto costo de oportunidad. Casi una década después, nuevos programas de subsidio habitacional con integración social, el del Decreto 116 (2014) y, más reciente, el del Decreto 19 (2016), están teniendo éxito en producir numerosas unidades de vivienda de integración social, pero eso lo consiguen, en buena medida, por disponer de un monto significativamente superior de subsidio habitacional. areas of the city. Almost a decade later, new housing subsidy programs for securing inclusionary housing -Decree Law No 116 (2014) and Decree Law No 19 (2016)- have proved successful in producing numerous inclusionary housing units, mainly due to the availability of higher housing subsidies.

Despite reflecting two opposed approaches, these two experiences combined place-based aid and people-based aid strategies. In the case of Ribera Norte, it is worth noting the difficulties in moving informal dwellers to their new dwellings, largely owing to the social and political history of the area. The fact of complementing people-based aid strategies with specific people-based aid approaches, such as the provision of housing through subsidies, added participatory characteristics to this program. The successful production of inclusionary housing clearly the main objective achieved during the first stage of implementation of this Program (Salinas and Baeriswyl, 2017, p. 10), was mainly possible thanks to the support to the needs and aspirations of local residents. The urban-based approach used to revitalize the area was complemented with social and political support to beneficiaries.

As for San Alberto, the composition of subsidies during the first so-called "social inclusion" policy implemented by the Bachelet administration shows some place-based aid elements. The "social 
A pesar de tener enfoques diametralmente opuestos, las dos experiencias revisadas han mezclado el apoyo a lugares con el apoyo a personas. En Ribera Norte, es de destacar que el proceso de traslado de los pobladores de campamentos a la nueva vivienda, ha estado lleno de dificultades, derivadas en buena medida de la historia social y política del lugar. El hecho de haber suplementado el enfoque de apoyo a lugares propio del Programa con formas específicas de apoyo a personas, como la entrega de viviendas a través de subsidios, le fue dando un carácter participativo. El éxito en la producción de vivienda de integración social, sin duda el principal logro del Programa en su primera etapa (Salinas y Baeriswyl, 2017, p. 10), se debió en buena medida al apoyo que se supo dar a las necesidades y aspiraciones de esos residentes del lugar. El foco urbanístico en la recuperación del área tuvo como complemento un trabajo, más social y político, de apoyo a quienes debían ser los beneficiarios de la vivienda que se construiría en el área del Programa.

En San Alberto, la composición de subsidios con que se armó esta primera política "de integración social" bajo la administración Bachelet, muestra un componente de apoyo a lugares. El "bono de integración social", que premiaba a los compradores de clase media, tenía, en rigor, criterios espaciales. Obtendrían el bono con que complementarían su "subsidio habitacional" (voucher), quienes elegían un lugar residencialmente mezclado para comprar su inclusion allowance" that benefitted middleclass homebuyers required users to meet spatial requirements. Vouchers would be granted to those purchasing housing in socially mixed developments. The combination between this kind of place-based aid approach contained in inclusionary housing policies and people-based aid strategies seems to be unavoidable as inclusionary housing is based on spatial elements.

\section{COMPARATIVE ANALYSIS 2: REMAINING IN HOUSING}

Given their location in socially diverse areas, social housing units have a potential value that exceeds the capacity of payment to residents. Invariably, each social program or inclusionary housing policy has this condition. The free operation of housing markets may lead to the displacement of beneficiaries. In this sense it is common to hear these dwellings will eventually be inhabited by people with higher income. 
vivienda. Este atisbo de apoyo a lugares en una política de vivienda de integración social combinada con ingeniería de apoyo a personas, es tal vez inevitable, dado que la definición de la vivienda de integración social está centrada en un atributo espacial.

\section{ANÁLISIS COMPARADO 2: PERMANENCIA}

Al estar en áreas de diversidad social, las unidades de vivienda para los hogares más pobres tienen un valor potencial que excede la capacidad de pago de sus beneficiarios. Invariablemente, todo programa o política de vivienda de integración social nace con esta condena. La libre operatoria de los mercados de vivienda tenderá a desplazar a dichos beneficiarios. Es usual que surjan voces tempranas que vaticinan que dichas viviendas serán ocupadas finalmente por personas de mayores ingresos.

¿Qué ha sucedido en Ribera Norte y qué en San Alberto? No hay información de desplazamiento de gente por los mercados de vivienda. Parece, en todo caso, muy pronto aún para concluir sobre el grado en que cada una de estas experiencias ha logrado evitar el desplazamiento. A pesar de ser más antigua, la vivienda de integración social de Ribera Norte se encuentra en un entorno aún en desarrollo.

¿Cómo se puede conjurar el peligro de desplazamiento? Están las medidas normativas, como la prohibición de vender o arrendar la vivienda por un tiempo determinado, o la norma de uso de
What has happened in Ribera Norte and San Alberto? There is no information about the displacement of people as the result of the action of housing markets. In any case, it is too soon to make conclusions as to what extend these programs managed to avoid the displacement of residents. Despite being the oldest initiative, Ribera Norte is located in an area that is still undergoing a development process.

How is it possible to avoid the displacement of people? There are policy measures such as the prohibition to sell or rent housing for a specific period of time or the land use regulation, which states that housing is built over land intended exclusively for residential purposes, as in the case of the "special areas of social interest", ZEIS, in Brazil. While the first of these measures is disappearing from Chilean housing policies, ZEIS measures are not available in Chile. In any case, these initiatives intended to protect socially mixed spaces may not succeed in urban cultures dominated by residential informality.

On the other hand, there is the spatial configuration generated by social mixing in areas with nonsegregated social housing. In this case there are two options: the dwellings of economically deprived users coexist with housing inhabited by people from different backgrounds within residential developments (such as apartment buildings or streets) or these dwellings are part of a microsegregated space within the development. 
suelo consistente en reservar los suelos donde está localizada la vivienda exclusivamente para dicho uso, como hacen las "zonas especiales de interés social”, ZEIS, de Brasil. Las primeras están más bien en retroceso en la política de vivienda en Chile, y normas de tipo ZEIS no existen. En todo caso, en culturas urbanas donde la informalidad residencial ha tenido, y sigue teniendo, tanta importancia, dichas defensas normativas de los lugares mezclados podrían no tener mayor efecto.

Por otra parte, está la configuración espacial de la mezcla social propia de los lugares con vivienda social no segregada. En lo básico, las alternativas son que la vivienda de los más pobres esté mezclada con la de los otros estratos al interior de los conjuntos residenciales (en los edificios de departamentos o en las calles de casas); o bien, que aquellas viviendas estén agrupadas dentro del conjunto en la forma de una microsegregación.

Cuando la vivienda para los hogares más pobres consiste en conjuntos residenciales de tamaño moderado y dispersos por el área socialmente heterogénea de intervención, especialmente si son en altura y tienen un cierre perimetral o un acceso visible y reconocible -como fue el caso de la vivienda que construyó el programa Rehabilitación Habitacional Popular, RHP, en el área central de la ciudad de México después del terremoto de 1985entonces es difícil que una familia de clase media vaya a desplazar a una de extracción popular.
When the dwellings of economically deprived people are located in medium-sized residential developments and distributed over a socially heterogeneous space, especially if the area is composed of gated high-rise buildings or there is a visible and recognizable access - as in the case of the dwellings built by the Social Housing Rehabilitation program, RHP, in the central area of Mexico after the 1985 earthquake, local dwellers are unlikely to be replaced by middle-class families. In fact, studies conducted by the RHP thirty years later show that most of families are still living in the same place (Esquivel, 2016, p. 125; López, 2016).

Dwellings built in Ribera Norte fit the above mentioned micro-segregation pattern. However, they are still exposed to local territorial stigmatization and the emergence of social issues. Despite defending people from displacement, micro-segregation turns local dwellers into more visible subjects, thus becoming victims of further discrimination.

However, if social mixing fits a 'pepper-pot' type scheme, beneficiaries are more likely to be replaced by gentrifying actors. The effort in avoiding making differences among dwellings of different prices in terms of aspect, facades, urban characteristics and local amenities for social inclusion purposes favors displacement. The advantage is that it makes stigmatization less likely to occur. This is the case of San Alberto. 
De hecho, estudios del RHP treinta años después muestran que la permanencia ha sido alta (Esquivel, 2016, p. 125; López, 2016).

La vivienda construida en Ribera Norte se ajusta a este esquema de microsegregación que, en todo caso, está expuesta a una estigmatización territorial de escala local, con los problemas que ello puede acarrear (o está acarreando) en materia de conflicto social. La microsegregación defiende al lugar del desplazamiento, pero hace más reconocible y "discriminable" a quienes habitan allí.

Cuando, en cambio, la mezcla social se ajusta al esquema tipo pimienta, entonces ese reemplazo de beneficiarios por gentrificadores es más fácil. El mismo esfuerzo por indiferenciar las viviendas de distinto precio en su aspecto externo, en las fachadas y en el urbanismo y las dotaciones del barrio, esfuerzo hecho con el fin de facilitar la integración social, vuelve la experiencia más susceptible al desplazamiento. Su ventaja, en cambio, es que la estigmatización es menos probable. Esta situación se ajusta al caso de San Alberto.

De tal forma, asociada a las alternativas de mezcla tipo pimienta o microsegregación posiblemente tome forma en los proyectos de vivienda de integración social un trade off entre permanencia y estigmatización. Transitar por los bordes de un equilibrio entre ambas, o saber construir un camino que logre sortear el trade off o disyuntiva, camino que seguramente será culturalmente específico, es
Therefore, associated to 'pepper-pot' types of mix and micro-segregation may lead to a trade-off between remaining in housing and stigmatization. Finding a balance between both perspectives or knowing how to build a path that manages to overcome the tradeoff is an important challenge for Latin American inclusionary housing policies. 
un importante desafío para nuestra política latinoamericana de vivienda de integración social.

\section{ANÁLISIS COMPARADO 3: INTEGRACIÓN SOCIAL Y FUNCIONAL}

En la zona de emplazamiento de San Alberto se han construido colegios, centros de salud y una serie de pequeños almacenes que entregan servicios básicos a la comunidad. Sin embargo, los lugares de trabajo y de estudio están mayoritariamente en el centro de Santiago o en el centro del municipio. Esta lejanía de servicios y oportunidades podría, además, entorpecer que la mezcla social devenga en integración social. Como los habitantes de San Alberto pasan gran parte del día fuera del barrio, existen pocas oportunidades de encuentro, señalan Maturana y Horne (2016). Aunque el contacto entre los vecinos es escaso y se restringe, en su mayoría, a un saludo cordial, los autores citados registraron altos niveles de satisfacción con el barrio, los que se explicarían por el paisaje natural, el aire de tranquilidad y la cercanía del lugar con un sitio de inversiones residenciales de alto estándar (Las Vizcachas).

Lo esporádico del encuentro podría ayudar a explicar la ausencia de conflictos que se registra en San Alberto y tal vez contribuya, al menos en un comienzo, a acomodar la diversidad social. Un 40 por ciento de los vecinos declara que no existen conflictos en el barrio y el 46 por ciento que, cuando ocurren, es fácil solucionarlos (Sabatini et al.,

\section{COMPARATIVE ANALYSIS 3: SOCIAL AND FUNCTIONAL INCLUSION}

Schools, health centers and different stores offering basic services have been built in the San Alberto area. However, most of places of work and study are located in the central areas of Santiago and Puente Alto. The remoteness of services and opportunities may prevent social mixing and social inclusion from occurring. According to Maturana and Horne (2016), since the inhabitants of San Alberto spend most of the day away from home, they have few opportunities to see each other. Though there is little contact among neighbors, which is often restricted to a friendly greeting, these authors found that residents are greatly satisfied with their neighborhood, mainly due to the presence of natural landscapes, peace and the proximity to Las Vizcachas, a site of high end residential development.

The lack of contact among residents may explain the absence of registered conflicts in San Alberto. This may contribute, at least in the early stages, to accommodate social diversity. For instance, 40 percent of residents state there are no disputes and 46 percent declare that, when these occur, conflicts are easily solved (Sabatini et al., 2013, p. 19). Most of these situations arise as the result of noise nuisance or (mis)use of common spaces, amongst others. 
2013, p. 19). La mayoría son por ruidos molestos, por uso de espacios comunes y otros usuales en condominios residenciales.

La integración funcional requiere de acceso a servicios y equipamientos urbanos cuyos precios o financiamiento, como el precio del suelo, tienden a ajustarse a los mejores pagadores del lugar. El costo de oportunidad de asignar suelo para usos por debajo de su renta potencial (la vivienda para los más pobres), en lo social, se refuerza con el voting with the feet de Tiebout (1956), en lo funcional, o tendencia de ajuste de los servicios locales al ingreso de los mejores pagadores.

Los terrenos disponibles para los proyectos de vivienda de integración social tienden a ser periféricos, donde ambos tipos de costos de oportunidad son menores. De esta manera y de no haber intervenciones estatales más decididas, como las expropiaciones de tierras o la fijación de cuotas obligatorias de vivienda social por conjuntos o áreas, la vivienda de integración social dispone de una franja precaria de factibilidad. Es una franja que se construye, con inventiva y decisión, en la frontera entre los lugares que los mercados empujan hacia la segregación de la homogeneidad social y los lugares que el capital inmobiliario promueve para producir y capitalizar brechas de renta con base en una gestión rentista de la heterogeneidad social, pero a costa de la exclusión de los más pobres.
Functional inclusion requires access to services and urban amenities whose prices or funding, such as the price of land, tend to adjust themselves to those with the ability to pay. The (social) opportunity cost of using land below its potential value (housing for the poor) is reinforced by the (functional) voting with the feet approach (Tiebout, 1956) or the adjustment of local services to the income of those with the ability to pay.

Available land for the construction of inclusionary housing projects tends to be located in peri-urban areas where both types of opportunity costs are reduced. In this way, in the event there are no determined state actions such as land expropriation or fixing compulsory social housing payments, inclusionary housing is unlikely to happen. With imagination and determination, the chances for the realization of inclusionary housing emerge in spaces where markets generate segregated social homogeneity, which produce and create income gaps according to a profit-oriented approach to social heterogeneity at the cost of the segregation of economically deprived people.

Chilean inclusionary housing policies are characterized by this lack of opportunities. While professionals such as Astaburuaga and Grandón make the most of these chances through perseverance and imagination, authorities use the trial and 
Esa franja precaria de oportunidad caracteriza hoy a la política chilena de vivienda de integración social. Mientras profesionales como Astaburuaga y Grandón la van explotando como pirquineros en base a la perseverancia y la inventiva, las autoridades lo han hecho recurriendo al ensayo y error, pero con reajustes recurrentes a los montos de los "subsidios habitacionales". Por eso, como ilustra la Tabla 2, los conjuntos de vivienda de integración social que se están construyendo hoy en Chile son más bien periféricos y se localizan en áreas de expansión urbana, que generalmente carecen de equipamientos y servicios. El permanente incremento del monto del subsidio no ha logrado asegurar una mejor localización de la vivienda, sino que, más bien, está financiando el incremento del precio del suelo, sobre ganancia que, en medida importante, es capitalizada por los promotores inmobiliarios.

Ribera Norte, en cambio, es aledaño alárea central de Concepción y cuenta con una amplia cartera de proyectos de servicios estatales y privados. Bascur registró la buena evaluación que los habitantes del Programa tienen de la integración funcional del área. También es alta la satisfacción con los niveles de integración social logrados, aunque en esa percepción tenga peso la integración de la participación y la movilización social, incluida aquella orientada a presionar a las mismas autoridades de Ribera Norte (Bascur, 2006 también registró los altos niveles de participación y de confianza error approach, but with recurring readjustments in the amount of "housing subsidies", to produce housing. As Table 2 illustrates, inclusionary housing developments under construction are mostly located in the urban expansion segments of peri-urban areas, which usually lack amenities and proper provision of services. The constant increase in the amount of subsidies, rather than securing better areas for the construction of housing, is funding the increase in the price of land, which is capitalized on by urban promoters.

Ribera Norte, however, is adjacent to the central area of Concepcion, thus enjoying the provision of different state and private services. As noted by Bascur, residents have positive opinions about functional inclusion within the area. There is also high satisfaction with the progress made in terms of social inclusion, despite the importance given to social engagement and mobilization including activities to put pressure on the heads of Ribera Norte. This author also noted high levels of participation and interpersonal trust among local residents (Bascur, 2006).

The success of this project lies in the fact that it prevented residents from being displaced, thus enabling them to maintain their personal functional support networks and respect the local sense of belonging, which was improved thanks to the intervention of this Program. 


\section{TABLA 2. DISTANCIA PROMEDIO DESDE LOS BARRIOS DE INTEGRACIÓN SOCIAL A SANTIAGO CENTRO, DICIEMBRE DE 2016.}

\begin{tabular}{lcc} 
Comunas $^{5}$ & Cantidad de proyectos & Distancia promedio del barrio al centro $(\mathrm{km})$ \\
\hline Centrales & 0 & - \\
\hline Pericentrales & 3 & 8,5 \\
\hline Periféricas & 21 & 14,7 \\
Contiguas a Santiago & 13 & 33 \\
\hline Total y promedio & 37 & 18,7
\end{tabular}

Fuente: elaboración propia en base a portal tuvivienda.cl. ${ }^{6}$

TABLE 2. DISTANCE BETWEEN INCLUSIONARY HOUSING NEIGHBORHOODS AND SANTIAGO CENTRO, DECEMBER, 2016.

\begin{tabular}{lcc|} 
Municipalities $^{5}$ & Number of projects & Average distance between neighborhoods and central areas (km) \\
\hline Central & 0 & - \\
\hline Peri-central & 3 & 8.5 \\
Peri-urban & 21 & 14.7 \\
Located immediately around & 13 & 33 \\
Santiago & 37 & 18.7 \\
Total/average & &
\end{tabular}

Source: Elaborated by the author based on information available at tuvivienda.cl ${ }^{6}$

$5 \quad$ Para el cálculo, las comunas clasificaron en: pericentrales (Cerrillos, Cerro Navia, Conchalí, Estación Central, Independencia, La Cisterna, La Granja, Lo Espejo, Lo Prado, Macul, Ñuñoa, Pedro Aguirre Cerda, Providencia, Quinta Normal, Recoleta, Renca, San Joaquín, San Miguel y San Ramón); periféricas (El Bosque, Huechuraba, La Florida, La Pintana, La Reina, Las Condes, Lo Barnechea, Maipú, Peñalolén, Pudahuel, Puente Alto, Quilicura, San Bernardo y Vitacura); y contiguas (Buin, Calera de Tango, Colina, Curacaví, El Monte, Isla de Maipo, Lampa, Padre Hurtado, Paine, Peñaflor, Pirque, San José de Maipo y Talagante).

6 Sitio web que alberga información sobre diferentes subsidios habitacionales que entrega el Estado chileno.
$5 \quad$ For estimate purposes, municipalities were classified as follows: pericentral (Cerrillos, Cerro Navia, Conchalí, Estación Central, Independencia, La Cisterna, La Granja, Lo Espejo, Lo Prado, Macul, Ñuñoa, Pedro Aguirre Cerda, Providencia, Quinta Normal, Recoleta, Renca, San Joaquín, San Miguel and San Ramón); peri-urban (El Bosque, Huechuraba, La Florida, La Pintana, La Reina, Las Condes, Lo Barnechea, Maipú, Peñalolén, Pudahuel, Puente Alto, Quilicura, San Bernardo and Vitacura); and located immediately around Santiago (Buin, Calera de Tango, Colina, Curacaví, El Monte, Isla de Maipo, Lampa, Padre Hurtado, Paine, Peñaflor, Pirque, San José de Maipo and Talagante).

6 Site hosting information about the different types of housing subsidies provided by the State.

ARTICLE: Support to places or to people? Two Chilean projects for socially integrated housing/Francisco Sabatini and Luis Vergara 
interpersonal entre los residentes de Ribera Norte). El gran acierto de este proyecto fue evitar el desplazamiento de los vecinos, permitiendo a éstos conservar sus redes personales de apoyo funcional y respetar el sentido de pertenencia al lugar, ahora mejorado por el Programa.

Los niveles de satisfacción residencial y ausencia de deseos de emigrar son comunes a ambos casos, pero de gestación bien distinta, aunque en ambos las redes sociales, las históricas de Ribera Norte o las inducidas por quienes gestionaron la demanda en San Alberto, parecen haber sido claves en los niveles y expectativas de integración social y funcional de estas experiencias.

\section{Conclusiones}

La segregación, ahora fortalecida en la escala regional con el despliegue del sector inmobiliario, es el problema urbano que la vivienda de integración social o "vivienda inclusiva" busca atajar. Pero los desafíos que esta enfrenta no son menores.

El apoyo a personas en que está construida la política habitacional chilena, y que ha sido el punto de arranque de la emergente política chilena de vivienda de integración social, de la que el proyecto San Alberto es representativo, ha tenido serias limitaciones: una ética, y con incómodas repercusiones ideológicas, ha consistido en subsidiar a los de mayores
Residential satisfaction levels and the lack of desire to emigrate are common to both cases; however, they are triggered in different circumstances, with historical -Ribera Norte- and demand-induced -San Alberto- social networks emerging as key elements behind social and functional inclusion levels and expectations.

\section{Conclusions}

The aim of inclusionary housing is to tackle the segregation issue, which has regionally grown as the result of the operation of real estate markets, thus posing major challenges for this type of policies.

People-based aid approaches, which are at the basis of Chilean housing policy, have served as starting point for the emergent Chilean policy for inclusionary housing programs. San Alberto as a prime example has had serious constraints: the first, an ethical issue involving uncomfortable ideological consequences, consists in providing subsidies to families with higher incomes to improve their willingness to live with poor residents; another issue refers to the emergence of considerable and constant inequality generated by the use of general funds that are mainly capitalized by urban promoters; The 
ingresos para mejorar su disposición a vivir con los más pobres; otra limitación es que comporta una inequidad importante y persistente, a saber, su financiamiento con fondos generales que, además, en parte importante, van a engrosar las rentas de la tierra que capitalizan los promotores. Una tercera es la de una localización periférica que está cercana a la frontera que podríamos establecer entre segregación residencial e integración a la ciudad, y que requiere un enorme desafío de energía y esfuerzo que no parece remontable más que ocasionalmente.

Sin embargo, los instrumentos (tipos de subsidios) con que se ha buscado canalizar el subsidio a la demanda a favor de la producción de lugares mezclados, involucran un camino de transformación de fondo. De hecho, lo que está ocurriendo en Chile es un tránsito desde el apoyo a personas hacia el apoyo a lugares; desde el apoyo a la masificación social del homo economicus, hacia el apoyo a la multiplicación de lugares socialmente mezclados (que idealmente, llegarían a ser socialmente integrados).

Incidentalmente, este tránsito ha puesto en evidencia algunos mitos y algunas miserias de la sociedad chilena. Pagarle a los de clase media para que vivan cerca de otros más pobres supone una cultura de clasismo que los casos concretos de conjuntos de vivienda de integración social están poniendo en duda, como los pocos estudios disponibles sugieren. La discriminación social en Chile existe, pero está lejos de ser absoluta y ubicua. Debemos estudiarla y entenderla mejor. third issue is associated with the peri-urban location of housing, which is on the borderline between residential segregation and urban inclusion, thus demanding a huge effort to address problem that appears to be only occasionally resolvable.

However, the mechanisms (types of subsidies) designed to channeling the subsidy to demand in favor of the production of socially mixed spaces involve a fundamental transformation. In fact, the current Chilean experience is moving from peoplebased aid strategies to place-based aid approaches; from the support of the social multiplication of homo economicus, towards the support of the massive creation of socially mixed spaces (which after all would eventually become socially inclusive).

Incidentally, these transformations have revealed some myths and negative aspects of Chilean society. Providing resources to middle-class families to coexist with poor groups involves the presence of class discrimination practices that are being challenged by concrete cases of inclusionary housing, just as suggested by few studies on this issue. Though far from being absolute and ubiquitous, social discrimination in Chile should be further explored and understood.

Finding funding mechanisms for inclusionary housing emerges as a task that awaits. In order to become economically sustainable, these policies should be associated with the resources derived from 
Una tarea pendiente, específica e importante es la del financiamiento de la vivienda de integración social. Para que esta sea económicamente sustentable, hay que conectarla con la riqueza que produce el desarrollo urbano, esto es, con la valorización del suelo.

Parece necesario rescatar el apoyo a lugares como fundamento de políticas de vivienda adecuadas y, en general, de una planificación urbana sustentable, tanto en lo social, ambiental como en lo económico. Antes que suma de lotes o de individuos racionales, la ciudad es un sistema de relaciones que crea y desarrolla bienes públicos con una importante dimensión espacial y territorial. Está constituida por lugares de encuentro, de oportunidades, de esparcimiento; por lugares de diversidad y creatividad; por lugares que también se deterioran al perder diversidad social o funcional, al congestionarse o contaminarse. El apoyo a lugares debe ser el foco de la planificación y las políticas urbanas, incluyendo a la política habitacional.

El debate suscitado en el último tiempo entre apoyo (tradicional) a lugares y apoyo (neoliberal) a personas, ha sido positivo porque nos permite reevaluar nuestro accionar a la luz del fracaso del neoliberalismo urbano y, en particular, del fracaso de su política de "subsidio habitacional". Las demoliciones sistemáticas de vivienda social sin problemas constructivos por el Estado chileno durante los últimos gobiernos son prueba elocuente de dicho fracaso. urban development, that is, the increase in the price of land.

Place-based aid programs should be at the basis of proper housing policies and sustainable urban planning in social, environmental and economic terms. Rather than being regarded as the sum of plots of land and rational individuals, the city is a system of relationships that create and develop public goods with an important spatial and territorial focus. It is composed of meeting, opportunity, recreation, diversity and creativity spaces, which become deteriorated as the result of congestion, pollution or the loss of functional and social heterogeneity. Urban planning and policies, including housing initiatives, should be based on place-based aid approaches.

The recent debate on place-based (traditional) or people-based (neoliberal) strategies has proved fruitful as it enables us to reevaluate our course of action in the light of the failure of the urban neoliberal approach, especially when it comes to "housing subsidy" policies. The systemic demolition of social housing on the part of the State over the last administrations is evidence of that.

The fact of merging place-based and people-based aid strategies, as emphasized by Galster (2017, p. 264) at the end of the introduction to the issue of Housing Policy Debate focused on both strategies, 
Y no resulta convincente que la salida sea la de adoptar un enfoque de compromiso entre ambas posturas, el apoyo a lugares y el apoyo a personas, como sugiere Galster (2017, p. 264) al final de su artículo introductorio al número de Housing Policy Debate dedicado a discutir ambos enfoques. Creemos que la orientación debe ser la de trabajar por el apoyo a lugares con fuerza y claridad conceptual, y que esa orientación debe complementarse con apoyos específicos a personas específicas para que estas no sean desplazadas de los lugares mejorados o no se atente contra su derecho de acceder y residir allí. Se trata de apoyos que nada tienen que ver con la noción ideológica de apoyo al homo economicus de los neoliberales. Requerimos pragmatismo para aprovechar las oportunidades que ocasionalmente ofrecen los mercados inmobiliarios -en línea con la estrategia de lugares que defiende Turner (2017) en ese mismo volumen (p. 306) - y con la visión comprehensiva de mayor escala geográfica y alcance temporal que es propia de la planificación.

La intervención de los mercados de suelo, tanto en lo referido al acceso al suelo como a su financiamiento, parece punto obligado de una política económicamente sustentable de vivienda de integración social. En este sentido, el programa Ribera Norte se nos presenta como superior que el proyecto San Alberto porque accede al suelo no segregado por fuera del mercado y porque se financia, al menos parcialmente, con la recuperación de plusvalías. Por cierto, las tierras estatales o las expropiaciones son seems not convincing. Proper approaches should be clearly and conceptually based on place-based aid strategies and complemented with specific support to specific people in order to avoid displacement from improved spaces or violate their right to remain in housing. These strategies are not associated with the homo economicus-based support promoted by neoliberals. Pragmatism is required to seize the opportunities provided by real estate markets -in line with Turner's support of place-based strategies in the same issue of Housing Policy Debate (p. 306) - and by taking a vision incorporating the greater geographic and temporal approaches common to planning.

The intervention of land markets, both in terms of access to land and funding opportunities, seems to be an essential condition when it comes to developing economically sustainable integration housing policies. In this sense, Ribera Norte is superior to San Alberto as it secures access to land from nonmarket related sources and is partially funded by the increase in the price of land. Despite state-owned lands or expropriation options are limited in nature, the international experience offers different land intervention instruments intended to secure access and funding of inclusionary housing (Calavita and Mallach, 2010).

This issue may also be further explored by disciplines such as sociology, anthropology and social psychology as well as by relevant experts, 
alternativas limitadas, pero hay una gama de instrumentos de intervención de los mercados de suelo con fines de acceso y financiamiento de la "vivienda inclusiva" que están disponibles en la rica experiencia internacional (Calavita y Mallach, 2010).

Hay un campo de trabajo también para la sociología, la antropología y la psicología social, lo mismo que para las profesiones de la forma, arquitectos y diseñadores. Aunque la distancia física entre personas de distintos estratos o clases es lo que define operativamente a la segregación, la espacialidad que incide sobre las interacciones sociales "en otredad" no se reduce a aquella. El campo de la vivienda de integración social es uno de experimentación y gran riqueza en materia de diseño espacial y arquitectura. La diferenciación de fachadas, el diseño de las circulaciones y la escala y tipología de la segregación o mezcla social interna al conjunto residencial, son variables que pueden incidir en las interacciones sociales, las dinámicas de conflicto, la fortaleza de la comunidad vecinal y, también, en el riesgo de desplazamiento de los beneficiarios vulnerables. architects and designers. Though segregation is operationally defined as the physical distance among people from different backgrounds, the effects of spatiality on social interactions are not related to such a description. Inclusionary housing is an experimental and rich field in terms of spatial design and architecture. The differences among facades, design and the scale and typology of segregation or social mixing within residential developments emerge as variables that may have an impact on social interaction, conflict dynamics, the strength of local communities and the impending displacement threat on vulnerable beneficiaries. 


\section{Referencias bibliográficas}

Alonso, W. (1964). Location and land use. Cambrigde: Harvard University Press.

Astaburuaga, J. y Grandón, M. (2013). Análisis y propuestas de politica habitacional. Documento inédito.

Bascur, H. (2006). Satisfacción residencial y capital social en el programa Ribera Norte. Revista CIS, 5(7), 44-59.

Boggs, E. (2017). People and place in low-income housing policy-unwinding segregation in Connecticut. Housing Policy Debate, 27(2), 320-326. https:// doi.org/10.1080/10511482.2016.1175087.

Borja, J. (1997). Planeamiento estratégico y proyectos urbanos: nuevos territorios y nuevas economías. En C. Hoshino (Ed.), Planeamiento y gestión urbana estratégica en América Latina (pp. 85-103). Santiago: United Nations Centre for Regional Development.

Borja, J. y Castells, M. (1997). Local y global; la gestión de las ciudades en la era de la información. Madrid: Taurus.

Brain, I. y Sabatini, F. (2006). Los precios del suelo en alza carcomen el subsidio habitacional, contribuyendo al deterioro en la calidad y localización de la vivienda social. Revista ProUrbana, (4), 1-13.

Calavita, N. y Mallach, A. (Eds.). (2010). Inclusionary housing in international perspective. Cambridge: Lincoln Institute of Land Policy.
Crane, R. y Manville, M. (2008). People or place? Revisiting the who versus the where of urban development. Land Lines, 1-7.

Dillman, K., Horn, K., y Verrilli, A. (2017). The what, where, and when of place-based housing policy's neighborhood effects. Housing Policy Debate, 27(2), 282-305. https://doi.org/10.1080/10511482.2016.11 72103.

Ducci, M. (1997). Chile: el lado obscuro de una política de vivienda exitosa. EURE, 23(69), 99-115. Recuperado de http://www.eure.cl/index.php/eure/ article/view/1164.

Esquivel, M. (2016). El Programa de Renovación Habitacional Popular y la tenencia de la vivienda. En R. Coulomb, M. Esquivel, y G. Ponce (Coords.). Habitar la centralidad urbana (II): prácticas y representaciones sociales frente a las transformaciones de la ciudad central (pp. 115-141). México: Instituto Belisario Domínguez.

Galster, G. (2017). People versus place, people and place, or more? New directions for housing policy. Housing Policy Debate, 27(2), 261-265. https://doi. org/10.1080/10511482.2016.1174432.

Garay, A. (2004) El montaje de una gran intervención urbana. En Lungo, M. Grandes proyectos urbanos (pp. 69-145). San Salvador: UCA Editores.

Hidalgo, R. (2007) ¿Se acabó el suelo en la gran ciudad?: Las nuevas periferias metropolitanas de la vivienda social en Santiago de Chile. EURE, 33(98), 57-75. https://doi.org/10.4067/ S0250-71612007000100004. 
Jacobs, J. (1961) The death and life of great American cities. New York: Random House.

Jacobus, R. (2015). Inclusionary housing: Creating and maintaining equitable communities. Cambridge, MA: Lincoln Institute of Land Policy.

López, S. (2016). Soy de la Guerrero y aquí ime quedo? Entre el derecho a la ciudad y la gentrificación. (Tesis Maestría en Urbanismo, sin publicar). Universidad Nacional Autónoma de México, México).

Marchant, C., Frick, J., y Vergara, L. (2016). Urban growth trends in midsize Chilean cities: The case of Temuco. Urbe. Revista Brasileira de Gestao Urbana, 8(3), 375-389. https://doi.org/10.1590/21753369.008.003.AO07.

Massey, D. (2015). The social science of affordable housing. Housing Policy Debate, 25(3), 634-638. https://doi.org/10.1080/10511482.2015.1039860.

Maturana, B. y Horne, R. (2016). Towards socially integrated housing in Chile: Assessing conviviality through two key housing projects. Open House International, 41(2), 6-14.

Ministra Saball en conferencia ONU-Habitat III: “Nuestro mayor desafío hoy es que los conjuntos habitacionales garanticen mixtura social". (2016, 19 de octubre). Recuperado de http://www.habitat3. cl/ministra-saball-en-conferencia-onu-habitat-iiinuestro-mayor-desafio-hoy-es-que-los-conjuntos-habitacionales-garanticen-mixtura-social/.

Mora, P., Sabatini, F., Fulgueiras, M., e Innocenti, D. (2014). Disyuntivas en la política habitacional chilena. Lincoln Institute of Land Policy.
Owens, A. (2017). How do people-based housing policies affect people (and place)? Housing Policy Debate, 27(2), 266-281. https://doi.org/10.1080/105114 82.2016.1169208.

Rodríguez, A. y Sugranyes, A. (2004). El problema de vivienda de los "con techo". EURE, 30(91), 53-65. https://doi.org/10.4067/ S0250-71612004009100004.

Sabatini, F. (2015). La ruptura del patrón de segregación y su significado teórico y práctico. A. Aguilar, e I. Escamilla (Coords.), Segregación urbana y espacios de exclusión. Ejemplos de México y América Latina (pp. 25-46). México: Instituto de Geografía UNAM, MA Porrúa.

Sabatini, F. (2016). ¿Podemos construir ciudades menos segregadas? En L. Álvarez, G. Delgado, y A. Leal (Coords.), Los desafíos de la ciudad del siglo XXI (pp. 439-455). México: UNAM.

Sabatini, F., Cáceres, G., y Cerda, J. (2001). Segregación residencial en las principales ciudades chilenas: Tendencias de las tres últimas décadas y posibles cursos de acción. EURE, 27(82), 21-42, 2001. https://doi.org/10.4067/ S0250-71612001008200002.

Sabatini, F., Mora, P., Polanco, M. y Brain, I. (2013). Conciliando integración social y negocio inmobiliario: seguimiento de proyectos integrados desarrollados por inmobiliarias e implicancias de politica. Lincoln Institute of Land Policy.

Sabatini, F., Rasse, A., Mora, P., y Brain, I. (2012). ¿Es posible la integración residencial en las ciudades chilenas?: Disposición de los grupos medios 
y altos a la integración con grupos de extracción popular. EURE, 38(115), 159-194. https://doi. org/10.4067/S0250-71612012000300008.

Sabatini, F., Wormald, G., y Rasse, A. (Eds.). (2013). Segregación de la vivienda social: ocho conjuntos en Santiago, Concepción y Talca. Santiago: Instituto de Estudios Urbanos y Territoriales, Pontificia Universidad Católica.

Salinas, E. y Baeriswyl, S. (2017). El Programa de Recuperación Urbana Ribera Norte; veinte años de aciertos y desaciertos de una política de proyectos urbanos en Chile. Revista de Urbanismo, (36), 114-130. https://doi.org/10.5354/0717-5051.2017.45676.

Sampson, R. (2012). Great American city: Chicago and the enduring neighborhood effect. Chicago: The University of Chicago Press.

Smith, N. (1979). Toward a theory of gentrification; a back to the city movement by capital, not people. Journal of the American Planning Association, 45(4), 538-548. https://doi. org/10.1080/01944367908977002.

Smolka, M. (2013). Implementing value capture in Latin America; policies and tools for urban development. Cambridge, MA: Lincoln Institute of Land Policy.

Tapia, R. (2011). Vivienda social en Santiago de Chile: análisis de su comportamiento locacional, periodo 1980-2002. Revista INVI, 26(73), 105-131. https:// doi.org/10.4067/S0718-83582011000300004.

Tiebout, C. (1956). A pure theory of local expenditures. Journal of Political Economy, 64(5), 416-424. https://doi.org/10.1086/257839.
Turner, M. (2017). Beyond people versus place: A placeconscious framework for investing in housing and neighborhoods. Housing Policy Debate, 27(2), 306314. https://doi.org/10.1080/10511482.2016.1164 739.

Zhang, J. y Zheng, L. (2015). Are people willing to pay for less segregation? Evidence from U.S. internal migration. Regional Science and Urban Economics, 53, 97-112. https://doi.org/10.1016/j. regsciurbeco.2015.05.002. 